\title{
A Retrospective: Michael M. Cernea (1934-)
}

\author{
Anthony Bebbington
}

'Development anthropology is a contact sport,' Michael Cernea likes to tell his students (Cernea and Freidenberg 2007). His career, from junior researcher in the Romanian Academy of Sciences in the early 1960s to joining the World Bank in Washington D.C. in 1974 as its first-ever in house staff sociologist, and then advancing there to the high level position of the World Bank's Senior Advisor for Social Policies and Sociology, is testament to this observation.

Cernea's has been a professional life characterised by constant high-stakes struggles over social development ideas within different bureaucratic and political settings. His has been a career where the thinking through of ideas, and the acting upon them, have been one and the same process. As a thinker in development, Cernea has to be understood as much in terms of his relationships to particular institutions as to development anthropology and sociology. Indeed, many might argue that Michael Cernea's most critical contribution has not been his intellectual work on the use of social science knowledge in crafting new social policies and designing development projects, or on the inherent risks of impoverishment in projects designed to reduce poverty; rather, his most critical and enduring achievements were the embedding of those ideas in World Bank policies and philosophy.

From the early 1970 s to the late 1990 s, Cernea contributed more than anybody in pushing the 'social envelope' at the Bank. He had the ear of Presidents and VicePresidents in the process, and from time to time was unrepentant in giving those ears a good chewing. He has been one of those quintessential reformists (and at times

I am very grateful to Michael Cernea for the interviews, materials and time he gave me during the preparation of this entry as well as for our conversations over the years. David Simon also graciously shared insights and information. An earlier version of this essay appears in D. Simon (ed.) Key Thinkers on Development (Second Edition, 2019). London: Routledge.

\footnotetext{
A. Bebbington $(\bowtie)$

Graduate School of Geography, Clark University, Worcester, MA, USA

e-mail: abebbington@ clarku.edu
} 
small ' $r$ ' revolutionaries) inside the Bank recognised by outside commentators and analysts as critical to any form of progressive change in the institution (Fox and Brown 1998).

How far personal history determines subsequent careers is always a matter of interpretation but in Michael Cernea's case there are at least apparent continuities. He grew up as part of the Jewish community in Jassy (Iaşi), a Romanian town close to the Russian border. As a child, he watched and experienced the violent unravelling of that community in the face of anti-semitism and fascism (Simon 2019). Along with all other Jewish children in the community, he was expelled from elementary school. Shortly before, his father had lost his job as an engineer for being a Jew. During the pogrom of Jassy in 1941, "one of the worst in Romania's history" (Simon 2019), he witnessed mass killings and his father badly beaten and impaired for life. The experience of persecution and resettlement was visceral-he was forced out of his home twice, first as a result of the pogroms (when the family went into hiding) and then in the face of the advancing German army. The experiences left him politically active and sensitised and after the war he became a member of the Socialist Youth Movement and a young journalist. Though initially a supporter of the Romanian Left's rise to government power in the post-war years, over time he grew more concerned at the directions taken by the regime. His $\mathrm{PhD}$ thesis, 'About Dialectics and Contradictions in the Socialist Society' (University of Bucharest, 1962), in which he tried to document factually the persistence of contradictions, conflicts and tensions within Romania's allegedly homogeneous society and structures, reflected these growing concerns. That he chose such a topic also presaged strategies of enquiry later in life at the World Bank-strategies in which he aimed to change an institution by fighting dysfunctionalities and challenging its foundational ideas from within that same institution.

As would later be the case at the Bank, this strategy generated resistance and socoupled with the effects of anti-Semitism in the Romania of the late 1950s - he had to wait 4 years simply to schedule the defence of his $\mathrm{PhD}$. Still, by the time he made his defence, the effects of the Khruschev thaw had changed the political context in Romania again, and Cernea was finally able to address the topic that really moved him, peasant economic rationality, although not without political fallout. This early work (Cernea 1970, 1971) operated at the boundaries of anthropology, sociology and rural economics, exploring cultural dimensions of productive strategies, and the relationships between peasant rationalities and co-operative agriculture. This concern for the socio-cultural foundations of the economy would reappear later in a different guise in his sustained questioning of what he referred to as the "economic reductionism' of the World Bank (see Cernea 1994 and below).

As the thaw continued, foreign scholars visited Romania in increasing numbers, a process that ultimately came to define a turning point both in Cernea's career (see his Malinowski Award lecture, Cernea 1996) as well as in the future that the World Bank was yet to have. Cernea was nominated by one of these visitors for a fellowship at the Center for Advanced Studies in the Behavioral Sciences (CASBS) at Stanford, one of the US's most prestigious academic fellowships. The politics behind Cernea being able to assume the fellowship were equally convoluted, 
but shortly before the meeting of Ceauşescu and Nixon (a meeting triggered by Ceauşescu's resistance to the Russian invasion of Czechoslovakia), Cernea finally received the visa allowing him to travel to California, albeit only in time for the latter part of the fellowship. His time there (1970-1) led to the distillation in English of his ideas on peasant society, but more importantly, to a friendship with US sociologist, Robert Merton, and a growing reputation in the USA.

The links between the year at Stanford, his initial contacts with the World Bank, and his being interviewed for a position in Washington were neither direct nor without major risks, but were very real. Whatever the case, in 1974-following a talk given at Bank headquarters on the role of the family plot in collective farms-he was offered a job. His position was to be the first sociologist to work in McNamara's newly created central Rural Development Division, a division that in many respects occupied the pivotal piloting role in McNamara's rural development-led approach both to poverty reduction (and, if more implicitly, to the taming of rural radicalisation) and to changing the Bank. Cernea took the Bank-much as he did Romania - as simultaneously an institution he worked (and largely lived) in, as an object of analysis, and as something he wanted to change. He believed that such change could come from the injection of sociological knowledge into the very foundations of the institution's way of interpreting and acting on the world.

In time, these convictions led him to study the Bank's project cycle in depth and explore the entry points for sociological knowledge in the processes through which the Bank designed and implemented its operations. As part of this project, he seized on the seminar as an instrument of institutional change and began inviting outside social scientists to speak to the Bank's staff on the different ways in which sociological knowledge and an awareness of the social dimensions of development could be brought into the project cycle. This cycle of seminars culminated in the book Putting People First (Cernea 1985), which-notwithstanding its focus on the World Bank-became one of the early foundational texts on participatory rural development. Cernea's introduction to the collection argued that the World Bank was in the business of financially induced development, but that for any such induced change to be successful it was imperative that the Bank understand the social structures that existed in the area of intervention and that could play the roles required of them in this process of induced development: echoes of Robert Merton's influence (Cernea 1985). Social science knowledge — and social scientists — were thus essential for the Bank, he argued (Cernea 1994).

This was a recurrent theme in his work: social science was to be conducted not for its own sake but for development's sake, and one of the key purposes of such social science was to challenge, constantly, the ideas underlying economists' and others' models of development. While the argument would be made intellectually-and Cernea has been a prolific writer-most strategically for him, it had to be made bureaucratically. If social science analyses were to have any teeth in the Bank, he argued that they had to be turned into bureaucratic instruments that made such knowledge a requirement of normal practice in the institution. Thus, another area in which Cernea contributed greatly was in developing and implementing directives and operational policies that required projects to have social appraisals. This 
contribution, if less visible to outside readers, was critical if any institutional change was to derive from his ideas. The easier part of this process was to generate the ideas and write them; the harder part was to get them through the Bank's approval process and then, once approved, keep them alive in the face of the constant pressure from other parts of the Bank to get rid of them.

The culmination of these arguments was a series of events beginning in late 1995 on the occasion of the Bank's formal recognition of Cernea's 20 years of working for the institution. At one of these events, he caught the new Bank President, James Wolfensohn, and made the case to him that social development had to be central to the poverty orientation that Wolfensohn was promoting. This led to a series of exchanges in which Cernea convinced Wolfensohn to create a social development task force that would report on the state of social development work in the institution. Again, negotiated and contested-'development anthropology is a contact sport' - this was a process that the Development Economics Vice-Presidency was able to contain and to some degree capture. But not entirely, for in 1997, and against the advice of the Bank's Chief Economist, Wolfensohn approved the creation of the Bank's first Social Development Department as part of the Bank's central vicepresidency for Socially and Environmentally Sustainable Development.

Cernea's work has also pushed the World Bank's thinking on the links between culture and development, on cultural patrimony and on the environment, on the concept of social policy and on articulating several Bank social policies. However, of most significance perhaps - both intellectually and also for human welfare-has been his work on involuntary resettlement, risk and vulnerability (Cernea and Guggenheim 1993; Cernea 1997; Cernea and Mathur 2008; Cernea 2018). Cernea joined the Bank during the period in which the large-scale infrastructure projects that would later bring the institution into such criticism, were being hatched. As early as 1978 he began elaborating guidelines for resettlement, which were subsequently issued under Robert McNamara as Bank policy (1980). Not long after came a sharp fight within the Bank over the provisions for resettlement in India's infamous Narmada Dam project. This became the seed for a review of the Bank's overall performance on resettlement during the first 5 years of existence of the new policy (Cernea 1986). A further product of this Bank-wide product was a subsequent paper, which integrated the original 1980 policy with the policy conclusions of the 1986 review, producing a stronger policy paper that further enhanced the initial policy and included operational guidelines, authored also by Cernea in 1988. This larger paper was also the first official Bank publication of its resettlement policy available publicly, and thus gained much more influence than the initial policy, which had been kept internal by the Bank (Cernea 1988, Bank Policy Technical Paper nr 80). This synthesis paper has been translated into many languages in different countries, including Chinese, Spanish, Turkish, Bahasa-Indonesia, Italian, and French and has had over a dozen print runs. If the 1986 review was critical, a later 1993-94 review of the entire Bank portfolio of projects causing displacement over the period 1986-1994 (Cernea et al. 1994) pulled even fewer punches. It systematically drew attention to the failures of the Bank to follow its own policy and highlighted what needed to be improved policy-wise and operationally. It also constituted one of 
Cernea's key_empirically sustained — statements on the way in which development inherently brings risk to people at the same time as bringing opportunity.

The resettlement reviews were not anti-development statements, but they did make clear that development processes handled irresponsibly, without adequate social science insight, without adequate consultation and involvement of poor people, are likely to increase vulnerabilities, and very often for the poorest. The intellectual core of this argument was later captured in his 'Impoverishment Risks and Reconstruction Model' (Cernea 1997, 2001, 2002, 2004; Cernea and McDowell 2000) of the eight risks that he came to identify as inherent in the process of displacement: landlessness, joblessness, homelessness, marginalisation, food insecurity, loss of access to common property resources, increased morbidity and community disarticulation (Cernea 1997; also Mahapatra 1999). The model typifies Cernea's intellectual and professional project in that it offers a framework intended not only to help understand risk, but also- through identifying and making explicit such risks - to trigger a response to this risk such that it might be mitigated even before its effects fully manifest themselves. Its purpose is to be analytical, predictive and methodologically useful. It became a leading model used internationally in research and policies about development triggered involuntary resettlement (Koenig 2002).

Cernea's contributions to development are many, reflected in a long list of publications, advisory roles and academic honours. Perhaps the most important among them, however, was to have changed an institution through the sustained and forceful insistence on a few ideas: that social science knowledge is critical to development, that induced development will fail in any meaningful sense if ordinary people are not involved in shaping the forms it takes, and that the cherished disembodied concepts of so much development theory cannot be considered separately from the social structures in which they are embedded. These ideas became embodied in the World Bank in different ways. A strong, mutually supportive, occasionally fractious network of social scientists was recruited to carry this agenda forward in their work in different parts of the institution; many of the ideas promoted by Cernea and these social scientists were built into operational directives and policies, project designs, and in some cases fully fledged loans; and the continued efforts of Cernea and his colleagues helped to elaborate a sort of public sphere within the Bank in which these ideas became common currency such that, even if many task managers, country directors and others found them annoying, they could not easily contest them openly or brazenly.

Thought of slightly more analytically, what Cernea did was to lead the building of the ideational, relational and normative bases for institutional change. What did not change, however, and this obviously exceeded the capacities of any network of social scientists, was the political economy of the World Bank as an institution that is ultimately dependent for its survival on its chief financial contributors (for its concessional lending) and on the approval and repayment of loans. Consequently today, much more so than in 2005 when the first version of this essay was written, the long-term survival of Cernea's and his colleagues' impacts on the Bank is less certain. 
The network of social scientists that carried Cernea's early ideas forward has now largely left the institution, and social science at the Bank has once again been rendered less powerful than it was in the 1990s and 2000s. Financially and politically powerful member countries, together with other epistemic communities within the Bank, push for the substantial watering down of the policies and directives that derived from Cernea's and colleagues' work. Cernea himself worries greatly about these reversals and came out publicly with a written criticism of the dilution of the Bank's safeguarding social and environmental policies, in which he argued for new ways of reinforcing them to protect the livelihoods and dignity of vulnerable people (Cernea 2018).

That said, even if there is a reversal in the shifts that Cernea helped win, to have changed the institution's practices during the three decades he spent there, means that his ideas, and his work, will have affected literally millions of lives forever.

Acknowledgement This essay was first published in the volume Fifty Key Thinkers on Development (Editor, David Simon, 2006), Routledge, Abingdon-Oxon, United Kingdom, and was updated in 2018.

\section{References and Major Works by Michael Cernea}

Cernea, M. (1970). Two villages, social structures and technical progress (in Romanian, senior author, research co-ordinator), Bucharest: Edit. Politica.

Cernea, M. (1971). Changing society and family change: The impact of the cooperative farm on the traditional peasant family. Stanford, CA: Center for Advanced Studies in Behavioral Sciences.

Cernea, M. (Ed.). (1985). Putting people first: sociological variables in rural development projects. New York: Oxford University Press.

Cernea, M. (1986). Involuntary resettlement in bank-assisted projects: A review of the application of bank policies and procedures in FY79-95 projects. AGR, Operations Policy Staff, World Bank, February.

Cernea, M. (1988). Involuntary resettlement in development projects: policy guidelines for bankfinanced projects. Washington, DC: World Bank.

Cernea, M. (1994). A sociologist's view on sustainable development. In I. Serageldin \& A. Steer (Eds.), Making development sustainable: From concepts to action (Environmentally sustainable development occasional paper series No. 2). Washington, DC: World Bank.

Cernea, M. (1996). Social organization and development anthropology. The 1995 Malinowski Award Lecture (ESD studies and monographs series, no. 6). Washington, DC: World Bank.

Cernea, M. (1997). The risks and reconstruction model for resettling displaced populations. World Development, 25(10), 1569-1588.

Cernea, M. (2001). Eight main risks: preventing impoverishment during population resettlement. In C. de Wet \& R. Fox (Eds.), Transforming settlement in Southern Africa (pp. 237-252). Edinburgh: Edinburgh University Press for the International African Institute.

Cernea, M. (2002). Cultural heritage and development: A framework for action in the Middle East and North Africa. Washington, DC: World Bank.

Cernea, M. (2004, September 22-23). The typology of development-induced displacements: Field of research, concepts, gaps and bridges. Paper to the US National Academy of Sciences conference on the study of forced migration, Washington, DC.

Cernea, M. (2018) Challenging the prevailing paradigm of displacement and resettlement. Its evolution and constructive ways for improving it. In M. Cernea \& J. Maldonado (Eds.), 
Challenging the prevailing paradigm of displacement and resettlement. Risks, impoverishment, legacies and solutions. Abingdon: Routledge.

Cernea, M. M., \& Freidenberg, J. (2007). Michael Cernea 'development anthropology is a contact sport' an oral history interview with Michael M. Cernea by Judith Freidenberg. Human Organization, 66(4), 339-353.

Cernea, M., \& Guggenheim, S. (Eds.). (1993). Anthropological approaches to resettlement: Policy, practice, and theory. Boulder, CO: Westview Press.

Cernea, M. M., \& Mathur, H. M. (Eds.). (2008). Can compensation prevent impoverishment?: reforming resettlement through investments and benefit-sharing. New York: Oxford University Press.

Cernea, M., \& McDowell, C. (Eds.). (2000). Risks and reconstruction: Experiences of resettlers and refugees. Washington, DC: World Bank.

Cernea, M., Guggenheim, S., Aronson, D., \& van Wicklin, W. (1994). Resettlement and development. The Bankwide review of projects involving involuntary resettlement 1986-1993. Washington, DC: World Bank.

Fox, J., \& Brown, D. (Eds.). (1998). The struggle for accountability: The World Bank. Cambridge, MA: MIT Press.

Koenig, D. (2002). Toward mitigating impoverishment in development-induced displacement and resettlement. Oxford: Refugees Studies Centre, University of Oxford.

Mahapatra, L. K. (1999). Resettlement, impoverishment and reconstruction in India. New Delhi: Vikas.

Simon, D. (2019). Holocaust escapees and global development: Hidden histories. London: Zed Books.

Anthony Bebbington is Milton P. and Alice C. Higgins Professor of Environment and Society in the Graduate School of Geography, Clark University, Professorial Research Fellow at the Global Development Institute, University of Manchester, Distinguished Professor at the Facultad Latinoamericana de Ciencias Sociales-Ecuador, and Honorary Professorial Fellow at the University of Melbourne. He is a Director of Oxfam America and has also worked at the World Bank, the Overseas Development Institute and the International Institute for Environment and Development. $\mathrm{He}$ is a member of the National Academy of Sciences and the American Academy of Arts and Sciences, and has been a Guggenheim Fellow, a Fellow at CASBS Stanford, a UK Economic and Social Science Research Council Professorial Fellow, an Australian Research Council Laureate Fellow, and has received Distinguished Scholarship honors from the American Association of Geographers. His research, primarily in Latin America, has addressed: extractive industries and socio-environmental conflict; NGOs and rural social movements; poverty and rural livelihoods; agricultural development; and the links between development interventions and political economy. Recent books include: Governing Extractive Industries: Politics, Histories, Ideas (Oxford University Press, 2018, with others); Subterranean Struggles: New Dynamics of Mining, Oil and Gas in Latin America (eds., University of Texas Press, 2013, with J. Bury); Social Conflict, Economic Development and Extractive Industries: Evidence from Latin America (ed., Routledge, 2012); and Minería, movimientos sociales y respuestas campesinas: una ecología política de transformaciones territoriales (ed., Instituto de Estudios Peruanos/Centro Peruano de Estudios Sociales, 2011). 
Open Access This chapter is licensed under the terms of the Creative Commons Attribution 4.0 International License (http://creativecommons.org/licenses/by/4.0/), which permits use, sharing, adaptation, distribution and reproduction in any medium or format, as long as you give appropriate credit to the original author(s) and the source, provide a link to the Creative Commons license and indicate if changes were made.

The images or other third party material in this chapter are included in the chapter's Creative Commons license, unless indicated otherwise in a credit line to the material. If material is not included in the chapter's Creative Commons license and your intended use is not permitted by statutory regulation or exceeds the permitted use, you will need to obtain permission directly from the copyright holder. 